\title{
Analysis on Problems and Measures in Music Education of Normal Universities under New Situation
}

\author{
Xiulei Ren \\ School of Music and Dance \\ Qujing Normal University \\ Qujing, Yunnan, China 655011
}

\begin{abstract}
Since ancient times, Confucian school has emphasized "using rites and music to govern the country". It shows that music has extremely high status in politics of Confucianism. It seems as though it has been beyond the imagination of people. In recent years, the economic and cultural construction of our country has reached outstanding achievements. Especially the music education of normal universities becomes main contents of cultural construction, because it concerns talent cultivation of music development in the future of our country. Meanwhile, as important carrier of quality-oriented education, music education attracts the attention of more and more people. With comprehensive reform and development of education cause in our country, music education carried out by normal universities is to cultivate more excellent music teachers and promote the development and prosperity of cultural education cause. This article comprehensively analyzes problems existing in music education of normal universities and puts forward corresponding suggestions and countermeasures to continuously improve music education in normal universities.
\end{abstract}

Keywords - cultural construction; normal universities; music education; quality-oriented education; problem; countermeasures

\section{INTRODUCTION}

Music education in normal universities mainly focuses on cultivating music teachers of middle and primary school. Teachers shoulder important mission and responsibility and they are important force to promote the construction of music culture of our country. Although music education and teaching of normal universities has achieved good results in today's teaching reform, especially made prominent performance on changes of teaching thought and improvement of teaching methods, we cannot ignore some realistic problems, which have serious impact on implementation of music education and teaching of our country.

\section{CURRENT SituAtion OF Music EdUCATION IN NORMAL UNIVERSITIES}

\section{A. The Number of Students in Music Education Major of Normal Universities Increases but the Overall Quality Is Not High}

In recent years, the cultural construction of our country has got a good development. With close attention paid by our country and departments of the society, the music education cause of normal universities also flourishes. A growing number of students enter themselves for an examination of music education major of normal universities. At the same time, our country also concentrates on educational reform and devotes to letting more students receive professional training of music knowledge, so the enrollment scale is enlarged ceaselessly.

The reason why the phenomenon appears is that the students of music major think these universities have relatively low requirements for academic records, which lead to the situation that quite a few freshmen have low cultural quality. Problems encountered by music teachers of normal universities in teaching process are showed as follows: Because students' cultural quality is low in general, their sensitivity in music will reduce and they lack the ability to understand music knowledge, which bring great difficulties for implementation of music teaching. It is impossible for teachers to finish music teaching work arranged by universities. It directly influences the cultivation of normal universities for excellent music teachers.

\section{B. Teacher Resources Are Lacked in Music Education of Normal Universities}

Nowadays, teachers of music education of normal universities are mainly students of professional conservatory of music. Influenced by a variety of ideas, students with excellent performance in school will wrongly put themselves in the place of "music experts". Some students with superior economic conditions in their family even reach for what is beyond their grasp and think becoming a music teacher in middle and primary school wastes their talent on a petty job, so they prefer to go abroad for continuing education. 
For students without superior economic conditions in their families, they may select occupations related to music education major at the beginning, but if they cannot make fortune by depending on the job that they are engaged in and it cannot fundamentally change their living standard and condition, they will give it up. It is more impossible for them to carry out music teaching activities in remote areas. These reasons fundamentally lead to the shortness of teacher resources in normal universities of our country.

\section{MAIN PROBLEMS In MUSic EdUCATION OF NORMAL UNIVERSITIES}

\section{A. College Has No Clear Training Objective}

Music education of normal universities mainly centers on cultivating excellent music teachers in middle and primary schools. For these students, the emphasis of teachers in teaching is different from that of professional conservatory of music. Professional universities of music art focus on cultivating excellent music talents. They pay attention to training students' comprehensive quality. Except for solid professional knowledge, they shall have other specialties of art.

\section{B. Infrastructure in Normal Universities Is Backward}

Music education is a very professional discipline. Except for demanding students to have higher music accomplishment, it needs universities to provide certain hardware facilities to assist music learning, such as musical instruments of piano and guitar required on music class. They are important material guarantee for teachers to carry out music education and teaching. However, many teachers in universities still teach through multimedia, traditional sound recorder and accordion. It will be in vain even though the teachers teach earnestly.

We should make it clear that we cannot learn music well by depending on teaching materials. If normal universities cannot provide the most basic music teaching facilities, how can they improve music level of students and integral quality of music teaching?

\section{Curriculum Provision in Normal Universities Is Unreasonable}

At present, music education of normal universities universally pays more attention to students' learning of theoretical knowledge and neglect courses with strong practicality. For example, if courses that need students to sing on the platform are directly changed into written assignments by teachers, they cannot get practical exercise, then how can they get certain results in music teaching? Theory and practice are inseparable. Only by integrating them can we cultivate more excellent music teachers.

Through visiting and investigating music education major of some normal universities, it is found that some professional teachers almost appropriate students to themselves. They think students of music major should concentrate on learning music courses and only pay attention to teaching specialized courses of their own. The teaching spirit of teachers is worthy of praise, but they exert pressure on students and the time are occupied by music courses, which will let students on the brim of collapse. They don't allow students to spend too much time in learning other courses, which will let students lack humanistic feelings. The creation and listening of music need certain emotional engagement. Without emotions, even the most beautiful music will become unglamorous.

\section{Music Teaching Materials Are of Poor Quality}

Music education of normal universities mainly focuses on cultivating excellent teaching for middle and primary schools. The contents of music teaching materials of many normal universities are too single and not systematic and professional. It greatly limits the cultivation of students in music education major of normal universities. Therefore, it is impossible to let quintessence of knowledge enter the mind and soul of students.

\section{E. Educational Concepts of Parents Are Backward}

Music education belongs to discipline of art major, which has relatively low requirements for students' academic records. Disciplines such as Chinese, mathematics and English are regarded as minor courses. On the contrary, the time for courses of music major is longer, which is also inevitable requirement of disciplines of music major.

However, exam-oriented education has negative effects on some parents, who think the time and method used by normal universities to arrange courses are seriously unreasonable and worry that their children cannot learn knowledge in school. Some of them even insist the idea of "misleading and causing harm to the young men" to argue with teachers and person in charge of the school. This behavior is extreme.

Another reason that we should pay attention to is that some students of music major in normal universities come from rural areas. Although the living standard in rural areas is improved to some extent in general, because many parents have low degree of education, even though they save money for children to receive education, they will not easily take out the money for children to learn music. They always think music cannot be directly turned into fortune, so it is understandable that they attach importance to academic records of children.

\section{F. The Arrangement of Students' Internship Is Unreasonable}

Just as other universities, students of music education major of normal universities also have internship. The purpose of internship is to let more students better and more quickly adapt to social development. Seriously speaking, students' internship is also a process of teaching practice and can effectively inspect the results achieved by students through music learning. However, in order to save time and cost, many normal universities seriously shorten the time for teaching practice of music education.

\section{G. Students Do Not Have Firm Foundation}

Students of music major in some universities do not have firm basic knowledge of music. They even cannot understand stave and go out of tune when singing. A variety of problems emerge in endlessly. The first and foremost reason is that some students do not receive systematic training for music knowledge before entering normal universities to learn music. They do not fundamentally realize the seriousness of problems. 
Music education and teaching in normal universities mainly focuses on cultivating music teachers for middle and primary schools. If things continue this way, it will be very difficult for them to be competent for the job that they may work on.

\section{CORRESPONDING COUNTERMEASURES FOR PROBLEMS IN MUSIC EDUCATION OF NORMAL UNIVERSITIES}

\section{A. Increase Students' Internship Time of Music Teaching}

The internship time of students in music major of most normal universities is only about half a year. And the internship is before graduation. The hasty arrangement of universities only becomes formalistic.

Therefore, students of music education in normal universities shall strengthen professional training and go out to practice according to property of their major. For example, during winter and summer vacation, they can support education in remote areas or participate in the program under which officials, doctors, scientists and college students go to the countryside to spread scientific and literacy knowledge and offer medical service to farmers organized by schools. They can not only gain experience but also give full play to theoretical knowledge bring more hope for children who are eager to receive music education. If things go on like this, students cultivated by music education major in normal universities can be qualified to teach music class independently in the future.

\section{B. Change Teaching Idea of Music Teachers in Normal Universities}

The purpose of music education and teaching in normal universities is to cultivate qualified and excellent music teachers for middle and primary schools of our country. In ordinary teaching process, teachers get along with students most frequently. When educating the future music teachers, they are in relatively antiquated mind state. Except for teaching students essential music education courses, they hardly will carry out education on music aesthetics, art aesthetics and music appreciation. Therefore, it is very important to change teachers' teaching idea to improve students' ability of music expression and artistic culture.

\section{Strengthen Construction of Cultural Quality of Teachers in Normal Universities}

Teachers of normal universities are backbone force of music education and teaching of normal universities, so superior leaders should pay more attention to teaching staff of music major. In terms of current situation that these schools are short of teachers, they may as well take students with prominent performance and expertise on music as the object of directed education and let them stay at school to teach students after graduation. It not only solves employment problems of them but also absorb excellent talents for universities.

When extending the number of music teachers in normal universities, it is also necessary to continuously cultivate their cultural quality, especially pay attention to training of professional knowledge for music teachers. In order to better carry out music education, the only way is to promote their cultural quality. Therefore, it is good to regularly let teachers in different normal universities carry out related academic research and discussion. Some normal universities with good economic condition can dispatch excellent music teachers on campus to investigate and learn in foreign top music art institutes and introduce effective music teaching methods of foreign countries, so it can effectively promote the development and progress of music education and teaching in normal universities of our country.

\section{Add Hardware Equipment of Music Education and Teaching}

In music education, music teaching facilities are the key to restrict development of music education. After finding the problem, normal universities shall timely equip infrastructure of music teaching, such as teaching appliance and sound equipment. For some normal universities, the national financial allocations may be few indeed and used to improve other problems on campus.

Therefore, normal universities can only create conditions through their own efforts and even can use local materials, such as make full use of wastes. Mineral water bottle can become useful musical instrument after being remolded. It is impossible for these things to replace professional musical instruments such as piano and electronic organ after all, so they shall increase investment if condition allowed.

\section{E. Give Opportunities for Students to Practice Music}

Except for teaching students basic theoretical knowledge, normal universities of music with good condition shall also pay attention to training students' practical abilities. To arrange music course in corresponding music room, they shall not save time and costs. Meanwhile, normal universities should make full use of spare time to organize students to carry out colorful literary and artistic activities and let students of music major gain experience when checking their level of music learning.

\section{IMPORTANCE OF MUSIC EDUCATION OF NORMAL UNIVERSITIES}

\section{A. Music Education Has A Long History}

Music culture of our country has a long history. According to ancient literature, it can be dated from the period of Yellow Emperor. Its birth has close relationship with development of history of China. Nowadays, quite a few excellent tracks are preserved as time goes by. With strengthening of globalization tendency, Chinese folk songs gradually go to the world, which also let more people overseas realize the endless charm of Chinese music again. With rapid development of Chinese music, music education of normal universities is born at the right moment. Each teacher of music major of normal universities shoulders significant missions and responsibilities.

\section{B. Conform to the Trend of Development of Times}

With development of economy and culture, our country greatly reforms the education. Music education of normal universities is one of the key points of it and can make 
education and teaching in universities get better teaching effects only from the perspective of students. It can effectively promote mass prosperity of music course only through conforming to the general trend of development of times.

\section{CONCLUSION}

Music education mainly focuses on training singing and music skills. Music education in normal universities is brought into the category of quality-oriented education of our country, which shows that music education in our country has become the main path for universities to carry out aesthetic education. It plays an important role in cultivating all around development of moral, intellectual, physical, aesthetics and labor education and improving the quality of the whole nation and constructing socialist spiritual civilization. The quality of music education in normal universities directly influences integral level of music education in schools of our country. At present, although our country pays higher attention to music education in normal universities, there are still many problems, which seriously restrict the development of music education of our country. Therefore, we shall consider the situation and put forward effective solutions. After all, music deeply influences the soul of young people. Without music education, they will not get more comprehensive development. It also goes against the reform of education in our country.

\section{REFERENCES}

[1] Bennett Reimer, translator: Xiong Lei. Philosophy of Music Education [J], People's Music Publishing House, 2003. 05.

[2] Yin Aiqing. Introduction to School Music Education and Methodology for Teaching Materials [J], People's Music Publishing House, 2007.09. 